\begin{abstract}
Iranica
Abstracta Iranica Revue bibliographique pour le domaine irano-aryen

Volume 37-38-39 | 2018

Comptes rendus des publications de 2014-2016
\end{abstract}

\title{
Antonio Panaino. «Power and Ritual in the Achaemenian Royalty »
}

\section{Astrid Nunn}

\section{(2) OpenEdition}

1 Journals

\section{Édition électronique}

URL : http://journals.openedition.org/abstractairanica/42618

DOI : 10.4000/abstractairanica.42618

ISBN : 1961-960X

ISSN : 1961-960X

Éditeur :

CNRS (UMR 7528 Mondes iraniens et indiens), Éditions de l'IFRI

Référence électronique

Astrid Nunn, «Antonio Panaino. "Power and Ritual in the Achaemenian Royalty » », Abstracta Iranica [En ligne], Volume 37-38-39 | 2018, document 22, mis en ligne le 10 mars 2018, consulté le 28 septembre 2020. URL : http://journals.openedition.org/abstractairanica/42618 ; DOI : https://doi.org/ 10.4000/abstractairanica. 42618

Ce document a été généré automatiquement le 28 septembre 2020

Tous droits réservés 


\title{
Antonio Panaino. « Power and Ritual in the Achaemenian Royalty »
}

\author{
Astrid Nunn
}

\section{RÉFÉRENCE}

Antonio Panaino. « Power and Ritual in the Achaemenian Royalty »,in M.J. Geller (éd.), Melammu. The Ancient World in an Age of Globalization. Proceedings of the Sixth Symposium of the Melammu Project, held in Sophia, Bulgaria, 2008. Edition Open Access, 2014, p. 235-239.

1 Le système du pouvoir achéménide a développé un certain nombre de motifs rituels, qui à la fois servaient à souligner le rôle des cérémonies publiques, de contrôle social et de fascination idéologique. Comme tous les documents achéménides soulignent le fait que le roi est une personne choisie par Ahuramazda, il est, selon l'A., raisonnable de supposer que le roi était considéré comme une image vivante d'une puissance supérieure et comme son représentant sur la terre.

\section{AUTEURS}

\section{ASTRID NUNN}

Université de Munich 